\title{
The most uncomfortable chronic pain in primary school teachers: differential between different body regions
}

\author{
Dor crônica que mais incomoda professores do ensino básico: diferenciais entre distintas \\ regiões do corpo
}

Flávia Lopes Gabani', Alberto Durán González², Arthur Eumann Mesas², Selma Maffei de Andrade²

DOI 10.5935/2595-0118.20180029

\section{ABSTRACT}

BACKGROUND AND OBJECTIVES: Chronic pain is a complex and multifactorial event. Very few research compare chronic pain according to the body region in teachers, a population with demanding workloads. The objective was to characterize the most uncomfortable chronic pain, reported by teachers, according to the body region.

METHODS: A cross-sectional study conducted from 2012 to 2013 with K-12 teachers from the 20 largest state schools in Londrina (PR). Chronic pain ( $\geq 6$-month duration) and the one that bothered the most were investigated. The Chi-square test (Yates) was used to compare the proportions of teachers with and without chronic pain, with a significance score of $5 \%$.

RESULTS: Among the 958 teachers, 408 (42.6\%) reported chronic pain, and the most disturbing pain were located mainly in the upper limbs, head, lower limbs and lower back $(n=321)$. Pain in the head region stood out for its longer duration, being classified as intense/unbearable and for strongly interfering with teachers' leisure and work. Pain in the upper and lower limbs frequently made it difficult for teachers to sleep. Teachers with low back pain had a greater proportion of leave of absence above 30 days compared to those with pain in other body sites.

CONCLUSION: We observed differences in the most uncomfortable pain according to the regions of the body. Pain in the head region stood out for its duration, intense/unbearable intensity and for interfering in teachers' leisure/work in greater proportion.

Keywords: Chronic pain, Occupational health, Teachers.

\footnotetext{
1. Universidade Estadual de Londrina, Departamento de Enfermagem, Londrina, PR, Brasil. 2. Universidade Estadual de Londrina, Departamento de Saúde Coletiva, Londrina, PR, Brasil.

Submitted in December 18, 2017.

Accepted for publication in April 10, 2018.

Conflict of interests: none - Sponsoring sources: none.

Correspondence to:

Av Roberto Koch, 60

86038-350 Londrina, PR, Brasil.

E-mail: lopesgabani@gmail.com

(C) Sociedade Brasileira para o Estudo da Dor
}

\section{RESUMO}

JUSTIFICATIVA E OBJETIVOS: A dor crônica é um evento complexo e multifatorial. Poucas pesquisas compararam a dor crônica conforme as distintas regiôes do corpo em professores, população com exigentes cargas de trabalho. Objetivou-se caracterizar a dor crônica referida, por professores, como a que mais incomodava, segundo a regiáo do corpo.

MÉTODOS: Estudo transversal realizado de 2012 a 2013 com professores dos ensinos fundamental e médio das 20 maiores escolas estaduais de Londrina (PR). Investigou-se a dor crônica ( $\geq 6$ meses de duração) e a que mais incomodava, na percepçáo dos professores. Para comparação de proporçôes utilizou-se o teste Qui-quadrado corrigido (Yates), considerando nível de significância de 5\%.

RESULTADOS: Entre 958 professores, 408 (42,6\%) reportaram dor crônica e as dores que mais incomodavam localizavamse principalmente em membros superiores, cabeça, membros inferiores e coluna lombar $(n=321)$. A dor na regiáo da cabeça destacou-se por maior duração, por ser classificada como intensa/ insuportável e por interferir no lazer e trabalho dos professores em maior proporçáa. Dor em membros superiores e inferiores dificultaram o sono dos docentes em maior frequência. Professores com dor na coluna lombar tiveram maior proporção de afastamento do trabalho acima de 30 dias comparados àqueles com dor em outros locais do corpo.

CONCLUSÁO: Observaram-se diferenças da dor que mais incomodava professores conforme as regióes do corpo. A dor na região da cabeça destacou-se pela duração, intensidade intensa/ insuportável e por interferir no lazer/trabalho dos professores em maior proporção.

Descritores: Dor crônica, Professor, Saúde ocupacional.

\section{INTRODUCTION}

Pain is a complex and multifactorial phenomenon, capable of harming the individual physically ${ }^{1}$ and psychologically ${ }^{2}$. The literature approach about pain in teachers, a population with demanding workloads, focus on the musculoskeletal disorders, which have a high prevalence ${ }^{3}$, and lower back pain is the most explored ${ }^{4,5}$.

A systematic review of the literature conducted by Erick and Smith ${ }^{5}$ found a prevalence of musculoskeletal pain among teachers varying from 39 to $95 \%$, mainly located in the chest, neck, and upper limbs regions. This variation in the prevalence reflects 
the diversities regarding the methodological criteria adopted in the different studies as the important variation of the sample size, the level of education where the interviewed teachers work, as well as the location of the pain and the time considered for the definition of chronic or acute pain.

Few studies specifically address chronic pain in teachers according to the definition recommended by the International Association for the Study of Pain (IASP) for epidemiologic research purposes, that is, pain with a 6-month duration or more ${ }^{6}$. Moreover, few compare the characteristics of chronic pain according to the affected region of the body, what could direct specific preventive measures 5 .

Therefore, this study tried to characterize the reported chronic pain as the most uncomfortable one, according to the body region, in teachers of the State Education System in a city of the South of Brazil.

\section{METHODS}

This is an epidemiologic, cross-sectional study, which is part of a project entitled "Saúde, estilo de vida e trabalho de professores da rede pública do Paraná - PRO-MESTRE" (Health, lifestyle, and work of teachers of the State Education System of Paraná PRÓ-MESTRE) - of the Post-Graduation Program in Collective Health of the State University of Londrina (UEL). The study was conducted in the city of Londrina, located to the North of the State of Paraná with a projected population of 515,707 inhabitants in the year 2012.

For this research, 20 schools in the urban area of the city with the highest number of teachers (about $70 \%$ of elementary and high school teachers) were selected, distributed in all regions of the urban zone. The sample size was calculated to provide sufficient statistical power to analyze the planned association in the larger study (PRÓ-MESTRE).

The instrument for data collection was composed by a form (to record the data obtained by the interviewers) and by a questionnaire, answered by the teacher after the interview. The questionnaire was applied in a way to preserve the teacher's privacy in more sensible questions, as, for example, household income. All the interviewers were previously trained, and a pilot study was conducted in a neighboring city as hands-on training of the interviewers, to adjust the instrument and to provide a better knowledge of the logistics to address the teachers. Data collection was from August to December 2012, and from February to June 2013.

Teachers with a temporary or permanent employment relationship with the State schools and working in the regular basic education (elementary and high school) were included. We did not include educators with an exclusive role in other teaching modalities (for example, youth and adult education), reinserted or away from the job, those with a professional period less than one year and diagnosed with malignant neoplasia, due to the difference between oncologic and non-oncologic pain.

The following were characterised as losses: (1) teachers who did not accept to participate in the study; (2) teachers whose contact was unsuccessful after the fifth attempt; (3) teachers who were on leave of absence regardless the reason, and who did not return within 30 days after the end of the data collection; and (4) interviews whew information about pain were ignored, that is, were not recorded by the interviewer.

Chronic pain was defined according to the international recommendation for scientific research, that is, lasting for six months or more ${ }^{6}$. To identify pain, teachers were asked: "Do you suffer from any type of chronic pain, that is, pain that annoys you for six months or more? In the case of a positive answer, the interviewer showed a card with the image of the human body asking the teacher to point to the sites of pain. More than one site were accepted. Teachers who reported chronic pain were also inquired about the location of the pain that most annoyed them, and only one answer was accepted, further classified according to the body region. The studied variables were divided into (1) demographic characteristics and life habits: gender, age group, body mass index (BMI), based on self-reported weight and height, and physical activity; (2) characteristics and consequences of the most annoying chronic pain in the teacher's perception: time, frequency and intensity of pain, interference of the pain in the leisure and work, and difficulty to sleep due to pain; (3) absenteeism and work capacity: absent from work due to health problems, time of leave of absence due to health problems, and work capacity in the perception of the interviewed regarding physical and mental requirements (very good, good, moderate, low and very low); e (4) pain treatment: seek a doctor to treat pain, recommendation of the medical treatment and treatment without medical indication. All the questions used in this study were elaborated by the PRÓ-MESTRE research team, based on the literature.

The project was approved by the Research Ethics Committee of the UEL under number CAAE 01817412.9.0000.5231. All the interviewed teachers signed the Free and Informed Consent Form.

\section{Statistical analysis}

The Epi Info software, version 3.5.4, was used to double type the data, and the Statistical Package for the Social Sciences (SPSS), version 19.0, for debugging and tabulation. The teachers who reported the most annoying pain in different body regions (head, lumbar spine, upper and lower limbs) were compared with the population who did not report pain, according to the demographic characteristic, lifestyle, absenteeism and work capacity. The Chi-square test was used with Yates correction for these comparisons, considering that there were statistically significant differences in the $p$-value of $p<0.05$. The characteristics and consequences of pain and treatment were addressed in a descriptive form, in absolute and percentage numbers.

\section{RESULTS}

Of the 1,505 teachers with an employment relationship with the selected institutions, 254 were not included since they worked in other teaching modalities, and 125 because they were reinserted or away from the function, remaining 1,126 eligible teachers. Of these, there were losses of 65 teachers who were on leave of absence and did not return up to 30 days of the data collection conclusion. Sixty-three that refused to participate in the study, 20 that were not found after the fifth attempt, and four for not 
having a history of chronic pain, totalizing 974 teachers. Nine teachers were excluded for having a time of professional activity less than one year, and seven due to a diagnosis of malignant neoplasia, resulting in the final population of 958 teachers. Chronic pain was reported by 408 (42.6\%) teachers.

Of the 408 teachers with chronic pain, six did not know to define in which area of the body was the most annoying pain, leaving 402 teachers. This exclusion was necessary because the subsequent questions were directed to only one region of the body. The regions reported as the ones where the most annoying pain was present were the upper limbs (94; 23.4\%), head (91; 22.6\%), lower limbs $(72 ; 17.9 \%)$ and lumbar spine (64; $15.9 \%$ ), totalizing 321 professors. Only teachers with pain located in these regions were analyzed, due to the reduced number of cases that reported pain in other regions of the body.

Comparatively to the population without pain, women predominated between those who reported the most annoying pain in the head $(87.9 \%$; $p<0.001)$ and in the upper limbs $(81.9 \%$; $p<0.001$, while the proportion of men was higher among those with back pain $(43.7 \%$; $\mathrm{p}=0.039)$. The number of teachers with age above 50 years was significantly higher among those who reported pain in the lower limbs (30.6\%; $\mathrm{p}=0.030)$, as well as those with BMI classified as overweight/obesity $(71.8 \%$; $\mathrm{p}<0.001)$ (Table 1$)$.

Among the teachers who reported that the most annoying pain was in the head, a high percentage reported that this pain was lasting for more than 10 years $(46.2 \%)$, with weekly occurrence $(51.1 \%)$ and of intensity from severe to unbearable (65.9\%). The teachers with pain in the upper and lower limbs reported that the pain has been present mainly between the last six months to five years ( 71.3 and $72.3 \%$, respectively), with a daily frequency and of moderate to unbearable intensity. The teachers who reported back pain said that its duration is of up to two years (31.3\%), with painful episodes from daily to weekly, and of moderate intensity. Pain in the head region was, proportionally, the most reported as interfering with teachers' leisure and work. Pain in the upper and lower limbs made it difficult to sleep in highest proportion (Table 2).

The percentage of leave of absence for health reasons was higher among teachers with pain, regardless the analyzed region, in comparison to those without pain (Table 3). Teachers who reported the most annoying pain in the lumbar spine had a higher frequency of leave of absence, above 30 days, in comparison with the population without pain $(\mathrm{p}<0.05)$. Regarding the capacity to work considering the physical demands, we noticed a higher rate of "low/ very low" among teachers with chronic pain in the upper limbs $(14.9 \% ; \mathrm{p}<0.001)$. There was a higher proportion of teachers with a headache who reported a "low / very low" capacity to work regarding the mental requirements, compared to teachers who did not report pain, but with no statistical significance $(\mathrm{p}=0.063)$.

The teachers with chronic pain in the upper limbs were the ones that, proportionally, demanded more medical care in the 12 months that preceded the research $(63.8 \%)$ and who have received treatment recommendation (Table 4). Pain relief with drugs was more frequently reported by teachers with pain in the head region $(70.5 \%)$. Teachers with pain in the lower limbs reported, in a higher proportion, an improvement with nonpharmacological treatment (33.3\%). Pain relief after medical treatment was reported, with higher frequency, by teachers with pain in the lumbar spine (58.6\%). Treatment without medical indication predominated among those with pain in the head region $(56.0 \%)$.

Table 1. Demographic characteristics, body mass index and physical activity of teachers according to the body region with most annoying chronic pain, Londrina (PR), 2012-2013

\begin{tabular}{|c|c|c|c|c|c|c|c|c|c|c|}
\hline \multirow{2}{*}{$\begin{array}{l}\text { Demographic characteristics and } \\
\text { life habits* }\end{array}$} & \multirow{2}{*}{\multicolumn{2}{|c|}{$\begin{array}{l}\text { Population without } \\
\text { pain } \\
(n=550)\end{array}$}} & \multicolumn{8}{|c|}{ Regions $(n=321)$} \\
\hline & & & \multicolumn{2}{|c|}{$\begin{array}{l}\text { Upper limbs } \\
\quad(n=94)\end{array}$} & \multicolumn{2}{|c|}{$\begin{array}{l}\text { Head } \\
(n=91)\end{array}$} & \multicolumn{2}{|c|}{$\begin{array}{l}\text { Lower limbs } \\
\qquad(n=72)\end{array}$} & \multicolumn{2}{|c|}{$\begin{array}{l}\text { Lumbar spine } \\
\qquad(\mathrm{n}=64)\end{array}$} \\
\hline \multicolumn{11}{|l|}{ Gender } \\
\hline Male & 206 & 37.5 & 17 & 18.1 & 11 & 12.1 & 24 & 33.3 & 28 & $43.7^{*}$ \\
\hline Female & 344 & 62.5 & 77 & $81.9^{\dagger}$ & 80 & $87.9^{\dagger}$ & 48 & 66.7 & 36 & 56.3 \\
\hline$\leq 30$ & 101 & 18.4 & 11 & 11.7 & 13 & 14.3 & 11 & 15.3 & 9 & 14.1 \\
\hline 31 to 40 & 175 & 31.8 & 23 & 24.5 & 29 & 31.9 & 13 & 18.0 & 15 & 23.4 \\
\hline 41 to 50 & 176 & 32.0 & 38 & 40.4 & 36 & 39.5 & 26 & 36.1 & 29 & 45.3 \\
\hline$\geq 51$ & 98 & 17.8 & 22 & 23.4 & 13 & 14.3 & 22 & $30.6^{* *}$ & 11 & 17.2 \\
\hline \multicolumn{11}{|l|}{ Physical activity } \\
\hline Sufficiently active & 174 & 31.6 & 19 & 20.2 & 17 & 18.7 & 25 & 34.7 & 13 & 20.3 \\
\hline Insufficiently active & 90 & 16.4 & 13 & 13.8 & 15 & 16.5 & 11 & 15.3 & 10 & 15.6 \\
\hline Inactive & 286 & 52.0 & 62 & 66.0 & 59 & 64.8 & 36 & 50.0 & 41 & 64.1 \\
\hline
\end{tabular}

${ }^{*}$ Records excluded with unreported information. ${ }^{* *} \mathrm{p}<0.05$; ${ }^{\dagger} \mathrm{p}<0.001$ (Chi-square test with Yates correction comparing pain in each body region with the population without pain). 
Table 2. Characteristics and consequences of most annoying chronic pain in teachers according to the body region, Londrina (PR), 2012-2013

\begin{tabular}{|c|c|c|c|c|c|c|c|c|}
\hline \multirow[t]{3}{*}{ Characteristics and consequences of pain * } & \multicolumn{8}{|c|}{ Regions $(n=321)$} \\
\hline & \multicolumn{2}{|c|}{ Upper limbs $(n=94)$} & \multicolumn{2}{|c|}{$\begin{array}{l}\text { Head } \\
(n=91)\end{array}$} & \multicolumn{2}{|c|}{$\begin{array}{l}\text { Lower limbs } \\
\qquad(\mathrm{n}=72)\end{array}$} & \multicolumn{2}{|c|}{$\begin{array}{l}\text { Lumbar spine } \\
\qquad(n=64)\end{array}$} \\
\hline & $\mathrm{n}$ & $\%$ & $\mathrm{n}$ & $\%$ & $\mathrm{n}$ & $\%$ & $\mathrm{n}$ & $\%$ \\
\hline \multicolumn{9}{|l|}{ Time with pain } \\
\hline 6 months to 2 years & 31 & 33.0 & 9 & 9.8 & 30 & 41.7 & 20 & 31.3 \\
\hline More than 2 years up to 5 Years & 36 & 38.3 & 15 & 16.5 & 22 & 30.6 & 13 & 20.3 \\
\hline More than 10 years & 10 & 10.6 & 42 & 46.2 & 6 & 8.3 & 18 & 28.1 \\
\hline \multicolumn{9}{|l|}{ Pain frequency } \\
\hline Daily & 51 & 54.3 & 12 & 13.3 & 44 & 65.7 & 26 & 40.6 \\
\hline Weekly & 32 & 34.0 & 46 & 51.1 & 17 & 25.3 & 29 & 45.3 \\
\hline Sporadic & 11 & 11.7 & 32 & 35.6 & 6 & 9.0 & 9 & 14.1 \\
\hline Intense/Unbearable & 44 & 46.8 & 60 & 65.9 & 29 & 40.8 & 23 & 35.9 \\
\hline \multicolumn{9}{|l|}{ Interference of pain in leisure } \\
\hline None & 8 & 8.6 & 2 & 2.2 & 6 & 8.4 & 5 & 7.8 \\
\hline Little/moderately & 48 & 51.6 & 41 & 45.1 & 33 & 45.8 & 38 & 59.4 \\
\hline Much/completely & 37 & 39.8 & 48 & 52.7 & 33 & 45.8 & 21 & 32.8 \\
\hline \multicolumn{9}{|l|}{ Interference of pain in work } \\
\hline None & 5 & 5.3 & 3 & 3.3 & 7 & 9.7 & 5 & 8.0 \\
\hline Little/moderately & 43 & 45.8 & 41 & 45.1 & 50 & 69.5 & 46 & 73.0 \\
\hline Much/completely & 46 & 48.9 & 47 & 51.6 & 15 & 20.8 & 12 & 19.0 \\
\hline \multicolumn{9}{|l|}{ Difficulty to sleep due to pain } \\
\hline
\end{tabular}

Table 3. Teachers' absenteeism and capacity to work according to the body region of the most annoying chronic pain, Londrina (PR), 2012-2013

\begin{tabular}{|c|c|c|c|c|c|c|c|c|c|c|}
\hline \multirow{3}{*}{$\begin{array}{l}\text { Absenteeism and capacity to } \\
\text { work* }^{*}\end{array}$} & \multirow{2}{*}{\multicolumn{2}{|c|}{$\begin{array}{c}\text { Population without } \\
\text { pain } \\
(n=550)\end{array}$}} & \multicolumn{8}{|c|}{ Regions $(n=321)$} \\
\hline & & & \multicolumn{2}{|c|}{$\begin{array}{l}\text { Upper limbs } \\
\quad(n=94)\end{array}$} & \multicolumn{2}{|c|}{$\begin{array}{l}\text { Head } \\
(\mathrm{n}=91)\end{array}$} & \multicolumn{2}{|c|}{$\begin{array}{l}\text { Lower limbs } \\
\qquad(n=72)\end{array}$} & \multicolumn{2}{|c|}{$\begin{array}{l}\text { Lumbar spine } \\
\qquad(n=64)\end{array}$} \\
\hline & $\mathrm{n}$ & $\%$ & $\mathrm{n}$ & $\%$ & $\mathrm{n}$ & $\%$ & $\mathrm{n}$ & $\%$ & $\mathrm{n}$ & $\%$ \\
\hline \multicolumn{11}{|c|}{ Leave of absence due to health problems } \\
\hline No & 294 & 53.5 & 37 & 39.4 & 37 & 40.7 & 29 & 40.3 & 26 & 40.6 \\
\hline Yes & 256 & 46.5 & 57 & $60.6^{\dagger}$ & 54 & $59.3^{\dagger}$ & 43 & $59.7^{\dagger}$ & 37 & 58.7 \\
\hline \multicolumn{11}{|c|}{ Leave of absence duration due to health problems (days) ** } \\
\hline 1 to 7 & 195 & 76.2 & 40 & 70.2 & 43 & 81.1 & 31 & 72.1 & 25 & 67.6 \\
\hline 8 to 30 & 45 & 17.6 & 10 & 17.5 & 7 & 13.2 & 9 & 20.9 & 5 & 13.5 \\
\hline$>30$ & 16 & 6.2 & 7 & 12.3 & 3 & 5.7 & 3 & 7.0 & 7 & $18.9^{\dagger}$ \\
\hline \multicolumn{11}{|c|}{ Capacity to work regarding the physical demands } \\
\hline Very good/good & 383 & 69.6 & 31 & 33.0 & 52 & 57.1 & 39 & 54.2 & 32 & 50.0 \\
\hline Moderate & 141 & 25.6 & 49 & 52.1 & 33 & 36.3 & 25 & 34.7 & 25 & 39.1 \\
\hline Low/very low & 26 & 4.8 & 14 & $14.9^{\dagger}$ & 6 & 6.6 & 8 & 11.1 & 7 & 10.9 \\
\hline \multicolumn{11}{|c|}{ Capacity to work regarding the mental demands } \\
\hline Very good/good & 396 & 72.0 & 67 & 71.3 & 58 & 63.7 & 58 & 80.6 & 45 & 70.3 \\
\hline Moderate & 126 & 22.9 & 21 & 22.3 & 23 & 25.3 & 10 & 13.9 & 16 & 25.0 \\
\hline Low/very low & 28 & 5.1 & 6 & 6.4 & 10 & 11.0 & 4 & 5.5 & 3 & 4.7 \\
\hline
\end{tabular}

${ }^{*}$ Records excluded with unreported information. ${ }^{* \star}$ Percentage calculated considering the teachers who missed work due to health problems. ${ }^{\dagger} p<0.05$ (Chi-square test with Yates correction comparing pain in each body region with the population without pain). 
Table 4. Treatment of the most annoying chronic pain in teachers according to the body region, Londrina (PR), 2012-2013

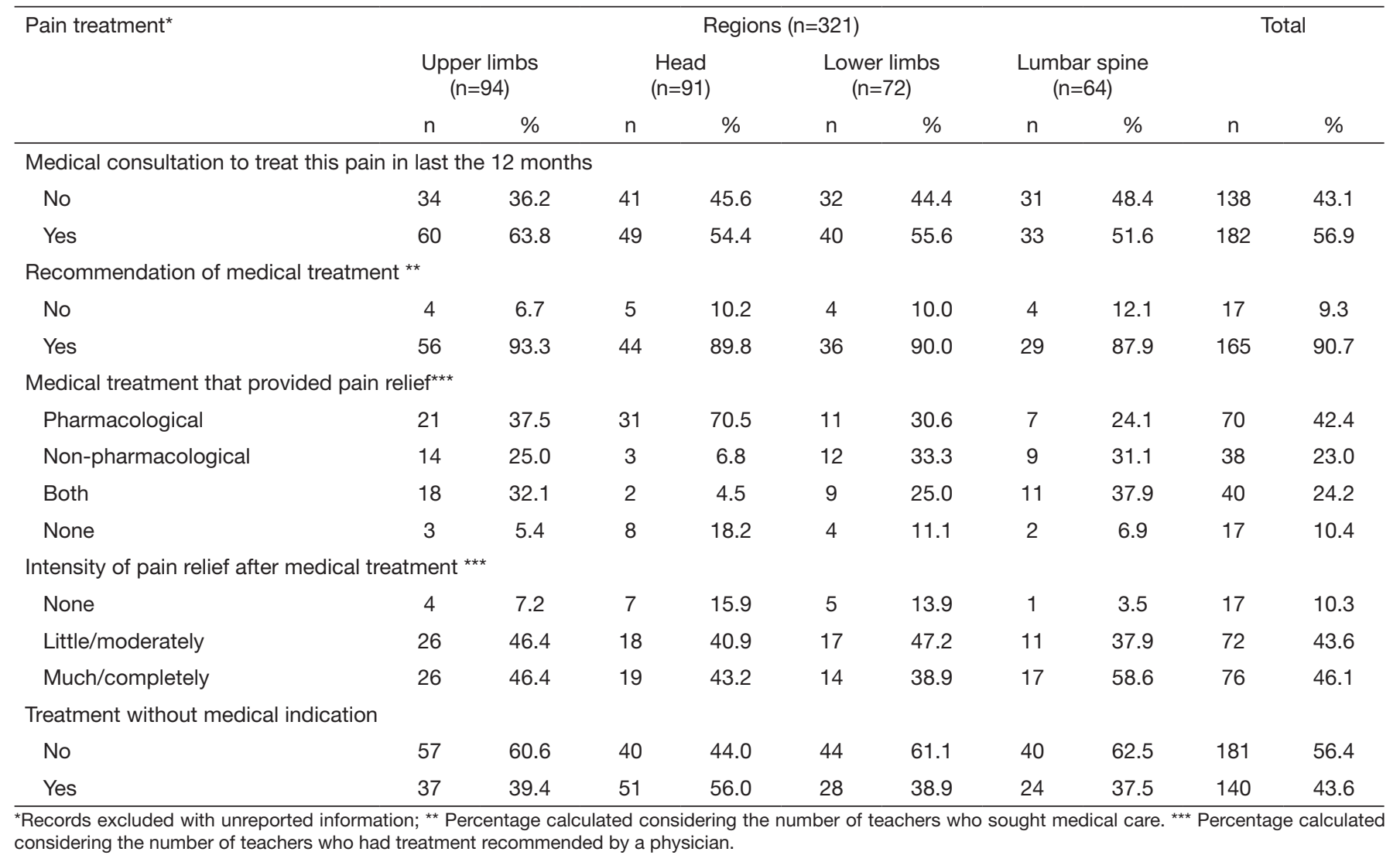

\section{DISCUSSION}

In this study, chronic pain in the head, although reported as less weekly frequency, was reported as severe/unbearable and with greater interference in leisure and work. The predominance of this type of pain in females, mainly when there is a diagnosis of a migraine, is a consensus in the literature, a result that is not exclusively identified in teachers ${ }^{7-9}$. In the present study, the specific site of pain origin in the head region was not determined, which makes it difficult to make comparisons. Vocal alterations, for example, are frequently observed in this professional category due to the intense use of the voice as a work instrument ${ }^{10}$.

Pain in the head region was the one that, proportionally, generated self-medication. The pharmacological resource for the relief of pain, whether by medical indication or self-medication, is frequently used when it is about an intense and disabling situation. Self-medication has cultural roots and is related to the difficulty to access medical care. The challenge becomes bigger when the objective is to alleviate migraines, which are usually intense, but with a good pharmacological therapeutical response with lowcost and easy-to-buy drugs ${ }^{11,12}$.

The use of drugs without a medical prescription and follow-up can lead to hypersensitivity reactions, addiction, GI bleeding, withdrawal syndrome, bacterial resistance, and even the increased risk of certain neoplasia and mask the evolution of some diseases ${ }^{13}$. Moreover, the teacher is seen as a role model by its students, who may reproduce the observed actions and behaviors.
In this context, the habit of self-medication must be discouraged so that it is not perpetuated by the students or other people who live with the teacher. Other studies also highlight the high frequency of self-medication in cases of headache ${ }^{11,14}$.

Regarding chronic pain in the upper and lower limbs, inadequate working postures and conditions are frequently associated with its onset and perpetuation ${ }^{15,16}$. As long as the working conditions are not goodness-of-fit, teachers will look for adaptations in an attempt to guarantee the quality of life and work. However, when this effort exceeds the physical and mental capacities, the emotional balance is disturbed with manifestation in the several organic systems. The suffering of the musculoskeletal system, in these situations, is a consensus in the studies, and the upper and lower limbs are severely affected in this profession ${ }^{5}$.

In this study, the teachers who reported the most annoying chronic pain in the upper and lower limbs have also reported, in a higher proportion, more trouble to sleep. But since this is a cross-sectional study, there is no way to establish a causal relation in this association. The relation between painful chronic conditions and sleep disorders can be bidirectional, meaning that the worse quality of sleep can also aggravate the pain process ${ }^{17,18}$. The functional disability when the limbs are involved in chronic pain is highlighted in some studies ${ }^{19,20}$, as well as the need for medical care ${ }^{21,22}$. It is not surprising that people with chronic pain seek medical care more frequently than others ${ }^{22,23}$. In this context, one Australian study conducted by Blyth et al. ${ }^{22}$ identified that the chronic pain process, when interfering significantly 
with the daily life activities may increase the number of medical visits in up to five times. Hospitalizations may double, even when the analysis is controlled due to possible variables of confusion. Pain relief in these patients is a challenge since, generally, these are people who put up with a long, painful process, presenting psychological suffering and physical and labor impairment, not to mention the therapeutical disbelief due to previous unsatisfactory results. These conditions can lead to non-compliance with the medical treatment and stimulate the use of therapeutic alternatives of unproven efficacy or the habit of self-medication ${ }^{24}$. As an adjuvant strategy, the search for alternative treatment is on the rise among these individual $s^{25}$.

The presence of musculoskeletal symptoms in the lumbar spine is found in several studies with teachers ${ }^{21,26}$. The highest prevalence of this pain in women was found in this and other studies ${ }^{26,27}$. However, in this study, when comparing pain in other sites of the body, there was a higher proportion of men with back pain. Yue, Liu and $\mathrm{Li}^{28}$ did not observe any difference between genders, but they associated a BMI $\geq 28 \mathrm{~kg} / \mathrm{m}^{2}$ as a risk factor for pain in the lumbar spine. Although the time of existence of this pain is proportionally smaller than in the other body regions analyzed, its presence serious due to its disabling nature. In this study, teachers with pain in this region of the body had a higher proportion of leave of absence, lasting more than 30 days, corroborating the results that show an association between back pain and long-term high absenteeism rates ${ }^{29}$.

Just like chronic pain in the other regions of the body, back pain requires pharmacological and non-pharmacological treatment, being the target of several scientific research ${ }^{30-33}$. However, since it is a complex and multifactorial pain that generate high public expenses and negatively impact the quality of life of the worker, it requires careful attention in its management. Studies that deepen the knowledge about the conditions associated with chronic back pain, using relevant adjustment variables, are necessary to plan more specific and directed actions.

Some investments in occupational health could minimize the reports of chronic pain in several regions of the body. The physical structure of the school should be planned and/or remodeled to provide more accessibility options, and the furniture and equipment must meet the teacher's ergonomic needs. It is important to foster strategies that minimize sedentarism, providing dedicated spaces and time for the practice of physical activities. Programs, in the school environment, to prevent and control pain must be with a priority, with the inclusion of professionals that master relaxation, stretching, and muscle strengthening techniques. Another aspect is the investment in the rehab of teachers already suffering from chronic pain. Pharmacological and non-pharmacological treatment is indicated to recover self-assurance and encouragement in the execution of the daily activities ${ }^{16,19,25}$.

\section{CONCLUSION}

In this study, the regions of the body with chronic pain that most annoyed teachers were the upper limbs, head, lower limbs and lumbar spine. Pain in the head region stood out for the long period of duration, the perceived intensity as intense/unbearable and for interfering with teachers' leisure and work in a higher proportion than in the other regions. Chronic pain in the upper and lower limbs frequently made it difficult for teachers to sleep. Teachers with chronic pain in the lumbar spine had a higher leave of absence rate, above 30 days, in comparison to those with pain in other body areas. It is important that future studies try to understand better the relationship between the work conditions and pain in the head region since, perhaps, it is the one that causes more damages to teachers.

\section{REFERENCES}

1. van Tilburg MA, Spence NJ, Whitehead WE, Bangdiwala S, Goldston DB. Chronic pain in adolescents is associated with suicidal thoughts and behaviors. J Pain. 2011;12(10):1032-9.

2. Oladeji BD, Makanjuola VA, Esan OB, Gureje O. Chronic pain conditions and depression in the Ibadan Study of Ageing. Int Psychogeriatr. 2011;23(6):923-9.

3. Ceballos AG, Santos GB. Factors associated with musculoskeletal pain among teachers: sociodemographics aspects, general health and well-being at work. Rev Bras Epidemiol. 2015;18(3):702-15.

4. Anuar NF, Rasdi I, Saliluddin SM, Abidin EZ. Work task and job satisfaction predicting low back pain among secondary school teachers in Putrajaya. Iran J Public Health. 2016;45(1):85-92.

5. Erick PN, Smith DR. A systematic review of musculoskeletal disorders among schoo teachers. BMC Musculoskelet Disord. 2011;12(1):260-71.

6. IASP. International Association for the Study of Pain. Classification of Chronic Pain 2012 [cited 201608 de agosto de 2016]; 2: [Available from: http://www.iasp-pain. org/PublicationsNews/Content.aspx? ItemNumber=1673\&navItemNumber=677.

7. Buse DC, Manack AN, Fanning KM, Serrano D, Reed ML, Turkel CC, et al. Chronic migraine prevalence, disability, and sociodemographic factors: results from the American Migraine Prevalence and Prevention Study. Headache. 2012;52(10):1456-70.

8. Diener HC, Solbach K, Holle D, Gaul C. Integrated care for chronic migraine patients: epidemiology, burden, diagnosis and treatment options. Clin Med. 2015;15(4):344-50.

9. Pahim LS, Menezes A, Lima R. Prevalência e fatores associados à enxaqueca na populaçấo adulta de Pelotas, RS. Rev Saúde Publica. 2006;40(4):692-8.

10. Ferreira LP, Giannini SP, Alves NL, Brito AF, Andrade BM, Latorre MD. Voice disorder and teaching work ability. Rev CEFAC. 2016;18(4):932-40.

11. Arrais PS, Coelho HL, Batista M, Carvalho ML, Righi RE, Arnau JM. Perfil da automedicaçấo no Brasil. Rev Saúde Pública. 1997;31(1):71-7.

12. Leite SN, Vieira M, Veber AP. Estudos de utilização de medicamentos: uma síntese de artigos publicados no Brasil e América Latina. Ciênc Saúde Colet. 2008;13(Suppl):793-802.

13. Aquino DS. Por que o uso racional de medicamentos deve ser uma prioridade? Ciênc Saúde Colet. 2008;13(Suppl):733-6.

14. Oliveira AL, Pelógia NC. Cefaleia como principal causa de automedicação entre os profissionais da saúde não prescritores. Rev Dor. 2011;12(2):99-103.

15. Chaiklieng $S$, Suggaravetsiri P. Risk factors for repetitive strain injuries among school teachers in Thailand. Work. 2012;41(Suppl 1):2510-5.

16. Korkmaz NC, Cavlak U, Telci EA. Musculoskeletal pain, associated risk factors and coping strategies in school teachers. Sci Res Essays. 2011;6(3):649-57.

17. Moldofsky H. Sleep and pain. Sleep Med Rev. 2001;5(5):385-96.

18. Finan PH, Goodin BR, Smith MT. The association of sleep and pain: an update and a path forward. J Pain. 2013;14(12):1539-52.

19. Branco JC, Silva F, Jansen K, Giusti PH. Prevalência de sintomas osteomusculares em professores de escolas públicas e privadas do ensino fundamental. Fisioter Mov. 2011;24(2):307-14.

20. Mango MS, Carilho MK, Drabovski B, Joucoski E, Garcia MC, Gomes AR. Análise dos sintomas osteomusculares de professores do ensino fundamental em Matinhos (PR). Fisioter Mov. 2012;25(4):785-94.

21. Carvalho AJ, Alexandre NM. Sintomas osteomusculares em professores do ensino fundamental. Rev Bras Fisioter. 2006;10(1):35-41.

22. Blyth FM, March LM, Brnabic AJ, Cousins MJ. Chronic pain and frequent use of health care. Pain. 2004;111(1):51-8.

23. Gerdle B, Björk J, Henriksson C, Bengtsson A. Prevalence of current and chronic pain and their influences upon work and healthcare-seeking: a population study. J Rheumatol. 2004;31(7):1399-406.

24. Kurita GP, Pimenta CA. Adesão ao tratamento da dor crônica: estudo de variáveis demográficas, terapêuticas e psicossociais. Arq Neuro-Psiquiatr. 2003;61(2-B):416-25.

25. Yeng LT, Stump P, Kaziyama HH, Teixeira MJ, Imamura M, Greve JM. Medicina física e reabilitação em doentes com dor crônica. Rev Med. 2001;80(spe2):245-55.

26. Cardoso JP, Ribeiro IQ, Araújo TM, Carvalho FM, Reis EJ. Prevalência de dor mus- 
culoesquelética em professores. Rev Bras Epidemiol. 2009;12(4):604-14

27. Silva MC, Fassa AG, Valle NC. Dor lombar crônica em uma população adulta do Sul do Brasil: prevalência e fatores associados. Cad Saúde Pública. 2004;20(2):377-85.

28. Yue P, Liu F, Li L. Neck/shoulder pain and low back pain among school teachers in China, prevalence and risk factors. BMC Public Health. 2012;12(1):789-96.

29. Axén I, Leboeuf-Yde C. Trajectories of low back pain. Best Pract Res Clin Rheumatol. 2013;27(5):601-12

30. Brazil A, Ximenes AC, Radu AS, Fernades A, Appel C, Maçaneiro C, et al. Diagnóstico e tratamento das lombalgias e lombociatalgias. Rev Bras Reumatol. 2004;44(6):419-25.

31. Montenegro SM. Análise da hidroterapia em mulheres com dor lombar e relação com as atividades da vida diária. Fisioter Bras. 2014;15(4):263-8.

32. Rosa R, Dias CP, Roncada C. Efeitos da acupuntura na redução da dor lombar: uma revisão sistemática. Rev Pesqui Fisioter. 2016;6(2):167-78.

33. Shaheed CA, Maher CG, Williams KA, Day R, McLachlan AJ. Efficacy, tolerability, and dose-dependent effects of opioid analgesics for low back pain: a systematic review and meta-analysis. JAMA Intern Med. 2016;176(7):958:68. 